Check for updates

Cite this: RSC Adv., 2019, 9, 5738

Received 20th December 2018

Accepted 11th February 2019

DOI: $10.1039 / \mathrm{c} 8 \mathrm{ra} 10439 \mathrm{e}$

rsc.li/rsc-advances

\section{Cross coupling of benzylammonium salts with boronic acids using a well-defined $\mathrm{N}$-heterocyclic carbene-palladium(II) precatalyst $\uparrow$}

\author{
Tao Wang, (D) *ab Jiarui Guo, ${ }^{\text {ab }}$ Xiaojuan Wang, ${ }^{\text {ab }}$ Han Guo, ${ }^{\text {ab }}$ Dingli Jia, ${ }^{\text {ab }}$ \\ Hengjin Wang ${ }^{\mathrm{ab}}$ and Lantao Liu iD *ab
}

$\mathrm{N}$-heterocyclic carbene-palladium(॥)-catalyzed cross-coupling of benzylammonium salts with arylboronic acids for the synthesis of diarylmethane derivatives via $\mathrm{C}-\mathrm{N}$ bond activation has been developed. Notably, in the presence of the easily prepared and bench-stable Pd-PEPPSI precatalyst, the $\mathrm{Csp}^{3}-\mathrm{N}$ bond activation of the benzylammonium salt even proceeded smoothly in isopropanol at room temperature.
Studies on synthetic methods of diarylmethane derivatives have attracted considerable attention because the compounds are important structural units in organic synthesis, materials science and pharmaceutical development. ${ }^{1}$ Among the synthetic approaches explored, transition metal catalyzed Suzuki coupling is one of the most important and frequently used methods. Over the past decade, the most popular strategies for the cross coupling of benzyl halides ${ }^{2}$ and benzyl sulfonates ${ }^{3}$ with aryl boric acid using Pd-catalysis have been reported. Disappointingly, some obvious drawbacks are involved with the use of benzyl halides and benzyl sulfonates as the electrophiles. These reagents are sometimes difficult in terms of substrate tolerance and storage. During recent years, the transition metal catalyzed Suzuki coupling reactions by the $\mathrm{C}-\mathrm{N}$ bonds cleavage have been developed. ${ }^{4}$ Among them, the cross coupling of quaternary ammonium salts has been quite well explored because they are more easily available from amine precursors or benzyl halides and they are also stable to longterm storage. Since the pioneering work of MacMillan and coworkers in $2003,{ }^{5}$ with aryltrimethylammonium salts as the electrophiles in various catalytic reactions such as crosscoupling, ${ }^{6} \mathrm{C}-\mathrm{H}$ arylation, ${ }^{7}$ borylation ${ }^{8}$ and reductive carboxylation reactions ${ }^{9}$ have been carried out. Although excellent results have been obtained, the optimization and development of cross-coupling reactions involving $\mathrm{Csp}^{3}-\mathrm{N}$ bond cleavage of benzylammonium salts under mild conditions, such as in

\footnotetext{
${ }^{a}$ Henan Engineering Laboratory of Green Synthesis for Pharmaceuticals, School of Chemistry and Chemical Engineering, Shangqiu Normal University, Shangqiu, Henan, 476000, People's Republic of China. E-mail: wt67751726@126.com; liulto5@iccas.ac.cn; Fax: +86-0370-2595126; Tel: +86-0370-2595126

${ }^{b}$ Henan Key Laboratory of Biomolecular Recognition and Sensing, School of Chemistry and Chemical Engineering, Shangqiu Normal University, Shangqiu, Henan, 476000, People's Republic of China

$\dagger$ Electronic supplementary information (ESI) available: Characterization data and NMR spectra of the catalysis products. See DOI: 10.1039/c8ra10439e
}

aqueous media or at room temperature, are still worthwhile projects. ${ }^{10}$ In this present contribution, we have developed efficient catalytic systems ${ }^{11-13}$ for the Suzuki-Miyaura coupling of benzyl chlorides with arylboronic acids, producing the corresponding diarylmethane derivatives in high yields. In a recent communication, the N-heterocyclic carbene-palladium(II) complexes were also found to be active catalysts for the SuzukiMiyaura cross-coupling of $N$-acylsuccinimides with arylboronic acids via $\mathrm{C}-\mathrm{N}$ bond activation. ${ }^{14}$ Considering our successful experience with the applications of this complexes in the crosscoupling reaction, we then turned our recent interest to the coupling reaction between benzylammonium salt and arylboronic acids for the formation of diarylmethane derivatives. In such context, we herein report the first example of NHC-PdPEPPSI catalyzed coupling reactions of benzylammonium salts with arylboronic acids via $\mathrm{Csp}^{3}-\mathrm{N}$ bond activation under mild conditions (Scheme 1).

It is initiated by investigating the crossing coupling of 4methoxyphenyl boronic acid with benzyltrimethylammonium bromide 1a, which is readily prepared quantitatively via the reaction of trimethylamine and benzyl bromide. The details were shown in Table 1. The choice of base is crucial to the yield of the reaction (Table 1, entries 1-9). ${ }^{15}$ In the presence of the IPr-Pd-PEPPSI complex $4 a$ as the catalyst, $\mathrm{K}_{3} \mathrm{PO}_{4} \cdot 3 \mathrm{H}_{2} \mathrm{O}$ as the base in isopropanol at $70^{\circ} \mathrm{C}$, we were delighted to observe that the reaction gave the corresponding diarylmethanes

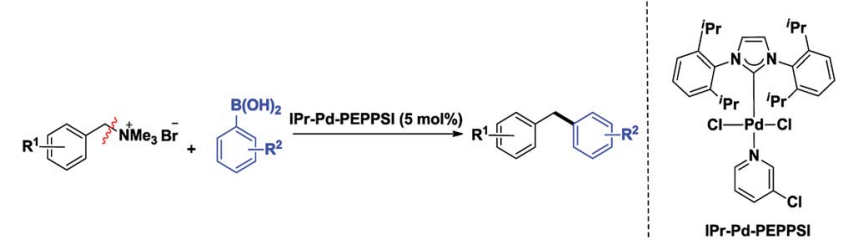

Scheme $1 \mathrm{NHC}-\mathrm{Pd}(॥)$ catalyzed coupling reactions of benzylammonium salts with arylboronic acids via $\mathrm{Csp}^{3}-\mathrm{N}$ bond activation. 
Table 1 Optimization of the cross-coupling reaction on substrate $1 a^{a}$
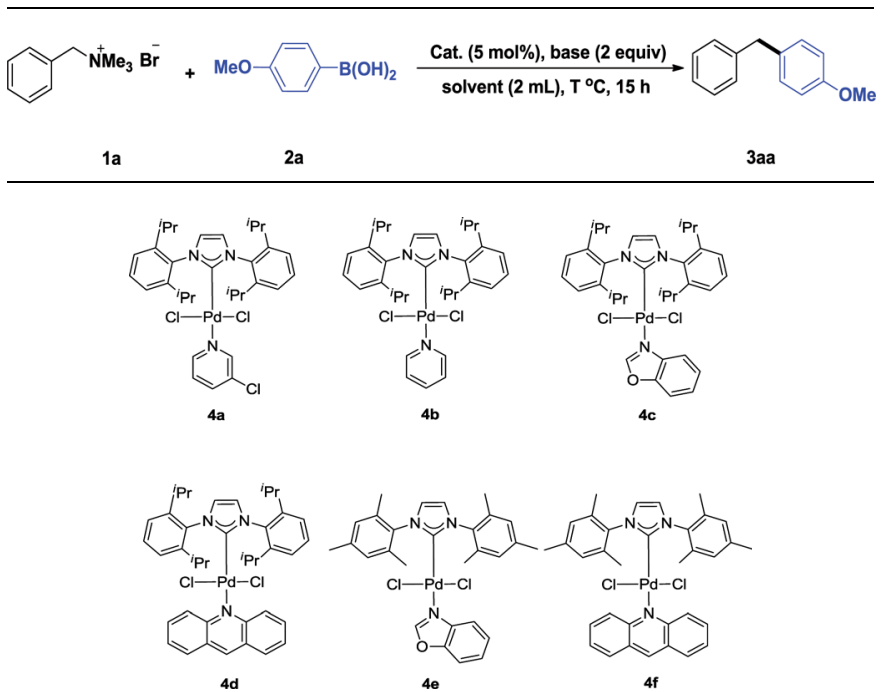

\begin{tabular}{|c|c|c|c|c|c|}
\hline Entry & Cat. & Base & Solvent & Temp $\left({ }^{\circ} \mathrm{C}\right)$ & Yield $^{c}(\%)$ \\
\hline 1 & $4 a$ & $\mathrm{KO}^{t} \mathrm{Bu}$ & ${ }^{\mathrm{i}} \mathrm{PrOH}$ & 70 & 89 \\
\hline 2 & $4 a$ & $\mathrm{Na}_{2} \mathrm{CO}_{3}$ & ${ }^{\mathrm{i}} \mathrm{PrOH}$ & 70 & Trace \\
\hline 3 & $4 a$ & $\mathrm{~K}_{2} \mathrm{CO}_{3}$ & ${ }^{\mathrm{i}} \mathrm{PrOH}$ & 70 & 91 \\
\hline 4 & $4 a$ & $\mathrm{NaHCO}_{3}$ & ${ }^{\mathrm{i}} \mathrm{PrOH}$ & 70 & Trace \\
\hline 5 & $4 a$ & $\mathrm{~K}_{3} \mathrm{PO}_{4}$ & ${ }^{\mathrm{i}} \mathrm{PrOH}$ & 70 & 70 \\
\hline 6 & $4 a$ & $\mathrm{~K}_{3} \mathrm{PO}_{4} \cdot 3 \mathrm{H}_{2} \mathrm{O}$ & ${ }^{\mathrm{i}} \mathrm{PrOH}$ & 70 & $>99$ \\
\hline 7 & $4 a$ & NaOAc & ${ }^{\mathrm{i}} \mathrm{PrOH}$ & 70 & Trace \\
\hline 8 & $4 a$ & $\mathrm{NaOH}$ & ${ }^{\mathrm{i}} \mathrm{PrOH}$ & 70 & 90 \\
\hline 9 & $4 a$ & $\mathrm{KOH}$ & ${ }^{\mathrm{i}} \mathrm{PrOH}$ & 70 & 98 \\
\hline 10 & $4 a$ & $\mathrm{~K}_{3} \mathrm{PO}_{4} \cdot 3 \mathrm{H}_{2} \mathrm{O}$ & THF & 70 & 47 \\
\hline 11 & $4 a$ & $\mathrm{~K}_{3} \mathrm{PO}_{4} \cdot 3 \mathrm{H}_{2} \mathrm{O}$ & 1,4-Dioxane & 70 & 98 \\
\hline 12 & $4 a$ & $\mathrm{~K}_{3} \mathrm{PO}_{4} \cdot 3 \mathrm{H}_{2} \mathrm{O}$ & EtOH & 70 & 88 \\
\hline 13 & $4 a$ & $\mathrm{~K}_{3} \mathrm{PO}_{4} \cdot 3 \mathrm{H}_{2} \mathrm{O}$ & Toluene & 70 & 30 \\
\hline 14 & $4 a$ & $\mathrm{~K}_{3} \mathrm{PO}_{4} \cdot 3 \mathrm{H}_{2} \mathrm{O}$ & $\mathrm{CH}_{3} \mathrm{CN}$ & 70 & 59 \\
\hline 15 & $4 a$ & $\mathrm{~K}_{3} \mathrm{PO}_{4} \cdot 3 \mathrm{H}_{2} \mathrm{O}$ & $\mathrm{H}_{2} \mathrm{O}$ & 70 & 54 \\
\hline${ }^{b} 16$ & $4 a$ & $\mathrm{~K}_{3} \mathrm{PO}_{4} \cdot 3 \mathrm{H}_{2} \mathrm{O}$ & ${ }^{\mathrm{i}} \mathrm{PrOH}$ & 70 & 82 \\
\hline 17 & $4 a$ & $\mathrm{~K}_{3} \mathrm{PO}_{4} \cdot 3 \mathrm{H}_{2} \mathrm{O}$ & ${ }^{\mathrm{i}} \mathrm{PrOH}$ & 50 & 99 \\
\hline 18 & $4 a$ & $\mathrm{~K}_{3} \mathrm{PO}_{4} \cdot 3 \mathrm{H}_{2} \mathrm{O}$ & ${ }^{\mathrm{i}}$ PrOH & rt & 96 \\
\hline 19 & $4 b$ & $\mathrm{~K}_{3} \mathrm{PO}_{4} \cdot 3 \mathrm{H}_{2} \mathrm{O}$ & ${ }^{\mathrm{i}} \mathrm{PrOH}$ & $\mathrm{rt}$ & 92 \\
\hline 20 & $4 c$ & $\mathrm{~K}_{3} \mathrm{PO}_{4} \cdot 3 \mathrm{H}_{2} \mathrm{O}$ & ${ }^{\mathrm{i}} \mathrm{PrOH}$ & $\mathrm{rt}$ & 90 \\
\hline 21 & 4d & $\mathrm{K}_{3} \mathrm{PO}_{4} \cdot 3 \mathrm{H}_{2} \mathrm{O}$ & ${ }^{\mathrm{i}} \mathrm{PrOH}$ & $\mathrm{rt}$ & 22 \\
\hline 22 & $4 e$ & $\mathrm{~K}_{3} \mathrm{PO}_{4} \cdot 3 \mathrm{H}_{2} \mathrm{O}$ & ${ }^{\mathrm{i}} \mathrm{PrOH}$ & $\mathrm{rt}$ & 42 \\
\hline 23 & 4f & $\mathrm{K}_{3} \mathrm{PO}_{4} \cdot 3 \mathrm{H}_{2} \mathrm{O}$ & ${ }^{\mathrm{i}} \mathrm{PrOH}$ & $\mathrm{rt}$ & 16 \\
\hline 24 & $4 a$ & $\mathrm{~K}_{3} \mathrm{PO}_{4} \cdot 3 \mathrm{H}_{2} \mathrm{O}$ & ${ }^{\mathrm{i}} \mathrm{PrOH}: \mathrm{H}_{2} \mathrm{O}(1: 1)$ & $\mathrm{rt}$ & 75 \\
\hline 25 & $4 a$ & $\mathrm{~K}_{3} \mathrm{PO}_{4} \cdot 3 \mathrm{H}_{2} \mathrm{O}$ & ${ }^{\mathrm{i}} \mathrm{PrOH}: \mathrm{H}_{2} \mathrm{O}(1: 1)$ & 50 & 97 \\
\hline 26 & $4 b$ & $\mathrm{~K}_{3} \mathrm{PO}_{4} \cdot 3 \mathrm{H}_{2} \mathrm{O}$ & ${ }^{\mathrm{i}} \mathrm{PrOH}: \mathrm{H}_{2} \mathrm{O}(1: 1)$ & 50 & 91 \\
\hline 27 & $4 c$ & $\mathrm{~K}_{3} \mathrm{PO}_{4} \cdot 3 \mathrm{H}_{2} \mathrm{O}$ & ${ }^{\mathrm{i}} \mathrm{PrOH}: \mathrm{H}_{2} \mathrm{O}(1: 1)$ & 50 & 90 \\
\hline 28 & 4d & $\mathrm{K}_{3} \mathrm{PO}_{4} \cdot 3 \mathrm{H}_{2} \mathrm{O}$ & ${ }^{\mathrm{i}} \mathrm{PrOH}: \mathrm{H}_{2} \mathrm{O}(1: 1)$ & 50 & 86 \\
\hline 29 & $4 e$ & $\mathrm{~K}_{3} \mathrm{PO}_{4} \cdot 3 \mathrm{H}_{2} \mathrm{O}$ & ${ }^{\mathrm{i}} \mathrm{PrOH}: \mathrm{H}_{2} \mathrm{O}(1: 1)$ & 50 & 6 \\
\hline 30 & 4f & $\mathrm{K}_{3} \mathrm{PO}_{4} \cdot 3 \mathrm{H}_{2} \mathrm{O}$ & ${ }^{\mathrm{i}} \mathrm{PrOH}: \mathrm{H}_{2} \mathrm{O}(1: 1)$ & 50 & Trace \\
\hline
\end{tabular}

${ }^{a}$ All reactions were carried out using $1 \mathrm{a}(0.20 \mathrm{mmol}), 2 \mathrm{a}(0.40 \mathrm{mmol})$, base $\left(2.0\right.$ equiv.), cat. $(5.0 \mathrm{~mol} \%)$ in solvent $(0.1 \mathrm{M})$ for $15 \mathrm{~h} .{ }^{b}$ Cat. $(2.0 \mathrm{~mol} \%) .{ }^{c}$ Isolated yields.

quantitatively. Several other solvents including THF, EtOH, 1,4dioxane, toluene, $\mathrm{CH}_{3} \mathrm{CN}$ and $\mathrm{H}_{2} \mathrm{O}$ were tested, and the yield was not enhanced further (Table 1, entries 10-15). When $2.0 \mathrm{~mol} \%$ of complex $4 \mathrm{a}$ was tested, the yield of cross coupling product was obtained in $82 \%$ yield (Table 1 , entry 16 ). It is worth mentioning that the IPr-Pd-PEPPSI complex 4a still gave good yield at room temperature (Table 1, entry 18). Further screening
Table 2 Scope of the coupling reaction with respect to the arylboric acid

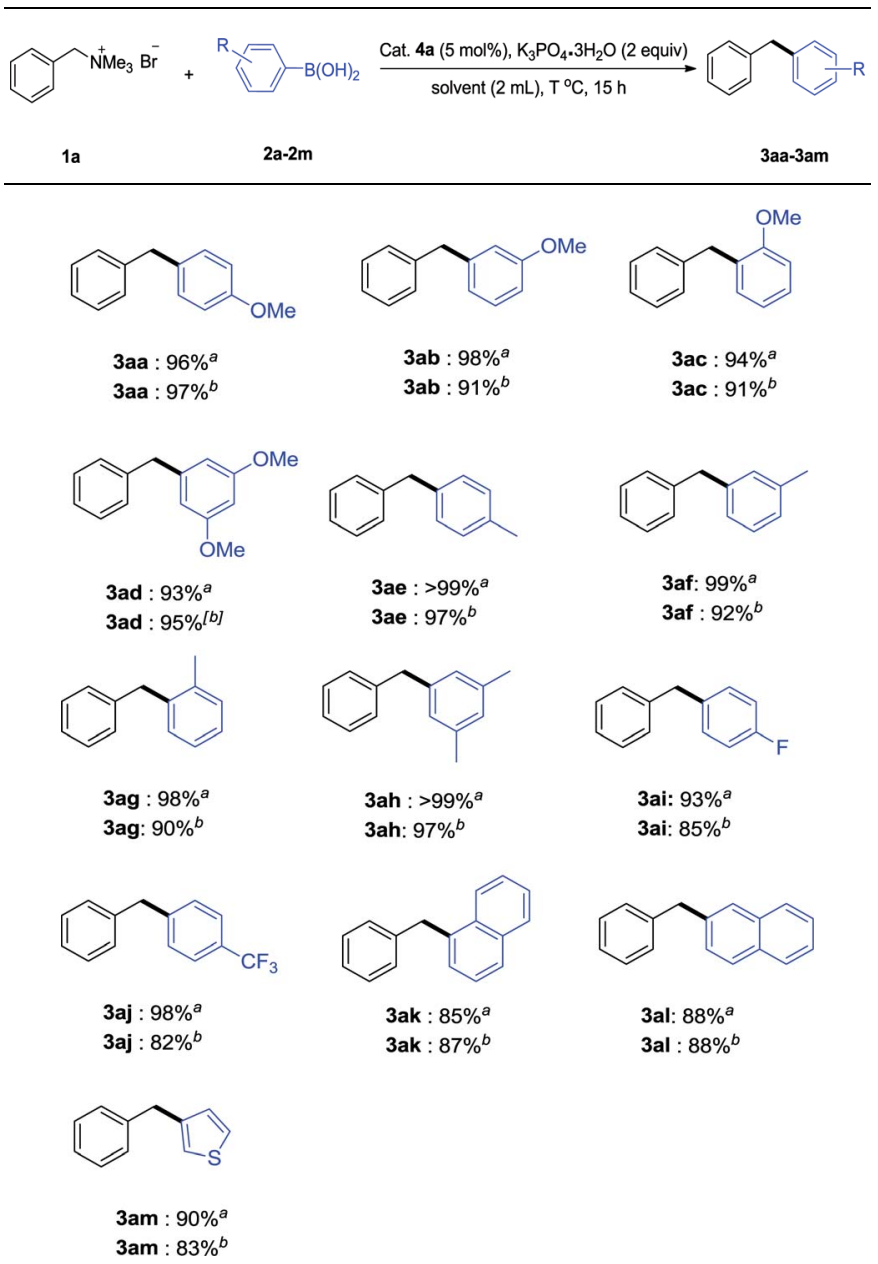

${ }^{a}$ All reactions were carried out using $1 \mathrm{a}(0.20 \mathrm{mmol}), 2(0.40 \mathrm{mmol})$, $\mathrm{K}_{3} \mathrm{PO}_{4} \cdot 3 \mathrm{H}_{2} \mathrm{O}$ (2.0 equiv.), cat. $4 \mathrm{a}(5.0 \mathrm{~mol} \%)$ in ${ }^{\mathrm{i}} \mathrm{PrOH}(0.1 \mathrm{M})$ at room temperature for $15 \mathrm{~h} .{ }^{b}$ All reactions were carried out using 1a $(0.20$ $\mathrm{mmol}), 2(0.40 \mathrm{mmol}), \mathrm{K}_{3} \mathrm{PO}_{4} \cdot 3 \mathrm{H}_{2} \mathrm{O}(2.0$ equiv), cat. $4 \mathrm{a}(5.0 \mathrm{~mol} \%)$ in mixture solvent $\left({ }^{\mathrm{i}} \mathrm{PrOH}: \mathrm{H}_{2} \mathrm{O}[\mathrm{v} / \mathrm{v}]=1: 1,0.1 \mathrm{M}\right)$ at $50{ }^{\circ} \mathrm{C}$ for $15 \mathrm{~h}$.

of NHC-Pd(II) catalysts demonstrates that the coordination environment of the NHC-Pd(II) complexes had an obvious effect on the yield (Table 1, entries 18-23). When a solvent mixture of isopropanol and water was tested, the yield of the product reduced to $76 \%$ (Table 1 , entry 24 ). In this case, heating to $50{ }^{\circ} \mathrm{C}$ was found to be necessary (Table 1 , entry 25 ). Then the performance of the other five NHC-Pd(II) complexes $4 \mathbf{b}-\mathbf{f}$ in this reaction condition was examined, and IPr-Pd-PEPPSI complex 4a was found to be optimal (Table 1, entry 25 vs. entries 26-30).

Since the reaction was performed in isopropanol at room temperature as well as in a solvent mixture consisting of isopropanol $(1.0 \mathrm{~mL})$ and water $(1.0 \mathrm{~mL})$ at $50{ }^{\circ} \mathrm{C}$ rather well, they were both applied as the reaction conditions in the following experiments to explore the scope of the cross coupling. As shown in Table 2, a series of aromatic boronic acids with benzyltrimethylammonium bromide were investigated in ${ }^{\mathrm{i}} \mathrm{PrOH}$ in the presence of $5.0 \mathrm{~mol} \%$ complex $4 \mathrm{a}$ and 2.0 equiv. $\mathrm{K}_{3} \mathrm{PO}_{4} \cdot 3 \mathrm{H}_{2} \mathrm{O}$ at room temperature for $15 \mathrm{~h}$. Gratifyingly, most of 
the coupling reaction proceeded rapidly and efficiently to provide the corresponding diarylmethane derivatives in excellent yields. It seems that the electronic effect and the steric effect of the substituents on the aromatic boronic acids have little effect on the reaction efficiency. No matter electron-donating (3aa-3ah) or -withdrawing (3ai-3aj) groups on the phenyl ring of boronic acids, good to excellent yields were obtained. The reaction was quite feasible with benzyltrimethylammonium bromide when the orthosubstituted aryl boronic acid was used (3ac and 3ag). In addition, in the case of 1-naphthylboronic acid or 2-naphthylboronic acid afforded in high reaction efficiency under the present reaction conditions (3ak-3al). Particularly, when heteroaromatic boronic acid, such as thienyl, was used as the substrate, high yield of the corresponding product was always observed (3am). Subsequently, a series of aromatic boronic acids with benzyltrimethylammonium bromide were investigated in ${ }^{\mathrm{i}} \mathrm{PrOH}-\mathrm{H}_{2} \mathrm{O}$ in the presence of $5.0 \mathrm{~mol} \%$ complex $4 \mathrm{a}$ and 2.0 equiv. $\mathrm{K}_{3} \mathrm{PO}_{4} \cdot 3 \mathrm{H}_{2} \mathrm{O}$ at $50{ }^{\circ} \mathrm{C}$ for $15 \mathrm{~h}$. All of the above substrates still worked well to afford the desired products in good to almost quantitative yields.

Inspired by these results and our attention was next turned to the cross coupling reaction of benzylammonium salts with 4methoxyphenyl boronic acid. As shown in Table 3, the reactions proceed smoothly to afford diarylmethanes in excellent yields. Roughly, the electron-donating group in the phenyl ring of benzylammonium salts showed some beneficial effect on the yields of the catalysis products. Benzylammonium salts bearing fluorine

Table 3 Scope of the coupling reaction with respect to the benzylammonium salts
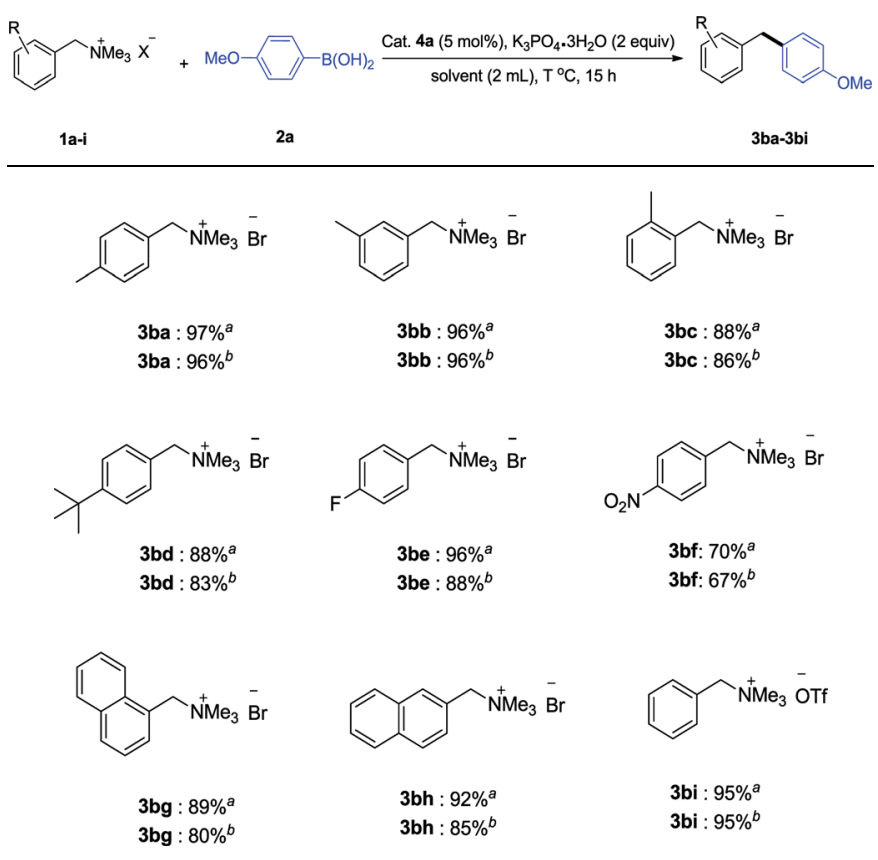

${ }^{a}$ All reactions were carried out using $1(0.20 \mathrm{mmol}), 2 \mathrm{a}(0.40 \mathrm{mmol})$, $\mathrm{K}_{3} \mathrm{PO}_{4} \cdot 3 \mathrm{H}_{2} \mathrm{O}$ (2.0 equiv.), cat. $4 \mathrm{a}(5.0 \mathrm{~mol} \%)$ in ${ }^{\mathrm{i}} \mathrm{PrOH}(0.1 \mathrm{M})$ at room temperature for $15 \mathrm{~h} .{ }^{b}$ All reactions were carried out using $1(0.20$ mmol), $2 \mathrm{a}(0.40 \mathrm{mmol}), \mathrm{K}_{3} \mathrm{PO}_{4} \cdot 3 \mathrm{H}_{2} \mathrm{O}(2.0$ equiv. $)$, cat. $4 \mathrm{a}(5.0 \mathrm{~mol} \%)$ in mixture solvent $\left({ }^{\mathrm{i}} \mathrm{PrOH}: \mathrm{H}_{2} \mathrm{O}[\mathrm{v} / \mathrm{v}]=1: 1,(0.1 \mathrm{M})\right)$ at $50{ }^{\circ} \mathrm{C}$ for $15 \mathrm{~h}$.

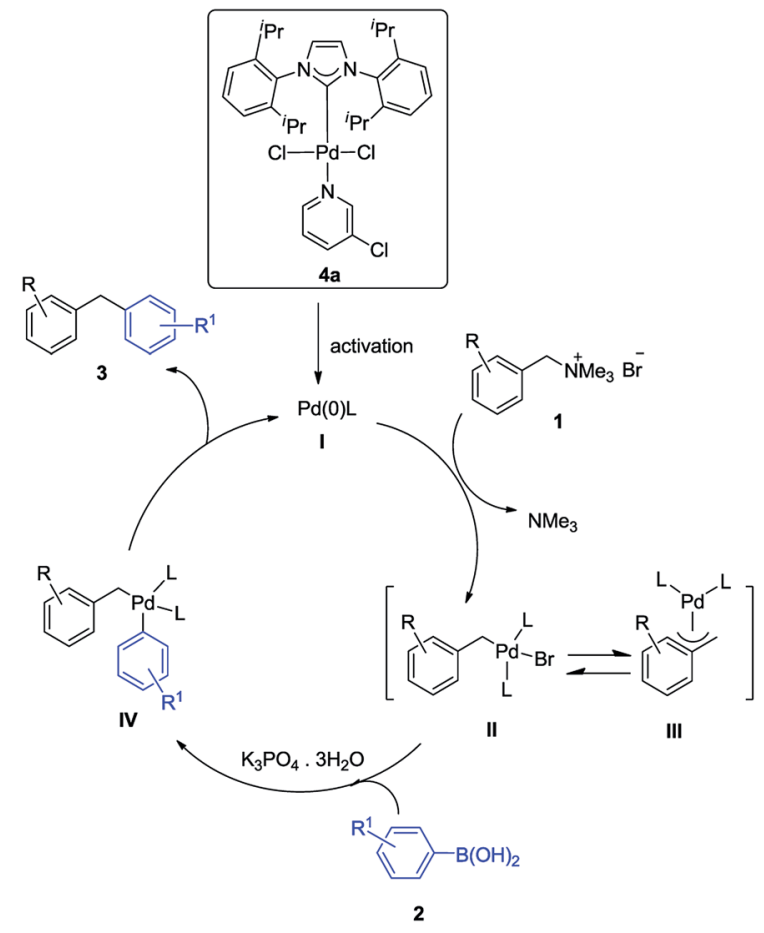

Scheme 2 Proposed reaction mechanism.

substituent showed good reactivity in this transformation (3be). Substrate 1 having naphthalene ring substituent was also suitable for such transformation to afford products $3 \mathbf{b g}$ and $\mathbf{3 b h}$ in good yields under appropriate conditions. In addition, when benzyltrimethylammonium triflate was used as the substrate, high yield of the corresponding product was always observed (3bi).

On the basis of the mechanism of previous reports ${ }^{\mathbf{1 0 b}}$ and our results, a putative reaction mechanism was then proposed in Scheme 2. First, oxidative addition of $\operatorname{Pd}(0)$ I produced in situ, with benzyltrimethylammonium salt 1 formed intermediate II with the release of trimethylamine. Then a transmetalation reaction of the intermediate II with aryl boronic acid converted to intermediate IV, which followed by reductive elimination to the product 3 with simultaneous regeneration of the $\operatorname{Pd}(0)$ catalyst.

\section{Conclusions}

In summary, we have developed the first example of NHC-Pd(II) catalyzed cross-coupling of benzylammonium salts with arylboronic acids to form diarylmethane derivatives, a very important skeleton in synthetic chemistry. The current process tolerates broad scope with respect to both the boronic acid and benzylammonium salts under mild conditions. Further exploration of these N-heterocyclic carbene-palladium(II) complexes and their catalytic applications in other reactions is in progress.

\section{Experimental}

\section{General remarks}

The catalytic reactions were carried out under a nitrogen atmosphere. Benzylammonium salts were prepared according to the literature method. ${ }^{\mathbf{1 6}}$ The N-heterocyclic carbene- 
palladium(II) complexes were synthesized according to our previous report. ${ }^{11 b}$ Solvents were dried by standard methods and freshly distilled prior to use. All other chemicals were used as purchased. ${ }^{1} \mathrm{H}$ and ${ }^{13} \mathrm{C}$ NMR spectra were recorded on a Bruker DPX 400 instrument using TMS as an internal standard.

\section{General procedure for the cross-coupling of benzylammonium} salts with arylboronic acids

A Schlenk flask was charged with the required benzylammonium salts 1a $(0.20 \mathrm{mmol}, 46.0 \mathrm{mg})$, (4-methoxyphenyl)boronic acid $(0.40 \mathrm{mmol}, 60.8 \mathrm{mg}$ ), N-heterocyclic carbene-palladium(II) complex $4 \mathrm{a}(5 \mathrm{~mol} \%, 6.8 \mathrm{mg}), \mathrm{K}_{3} \mathrm{PO}_{4} \cdot 3 \mathrm{H}_{2} \mathrm{O}(2.0$ equiv., 106.5 $\mathrm{mg})$, and ${ }^{\mathrm{i}} \mathrm{PrOH}(0.1 \mathrm{M})$ [or ${ }^{\mathrm{i}} \mathrm{PrOH}: \mathrm{H}_{2} \mathrm{O}[\mathrm{v} / \mathrm{v}]=1: 1,0.1 \mathrm{M}$ ]. The mixture was stirred at room temperature $\left[\right.$ or $\left.50{ }^{\circ} \mathrm{C}\right]$ for $15 \mathrm{~h}$ under $\mathrm{N}_{2}$. After cooling, the mixture was evaporated and the product was isolated by by preparative TLC on silica gel plates eluting with $\mathrm{CH}_{2} \mathrm{Cl}_{2}$ /petroleum ether to afford the diarylmethane. The purified products were identified by NMR spectra and their analytical data are given in the ESI. ${ }^{\dagger}$

\section{Conflicts of interest}

There are no conflicts to declare.

\section{Acknowledgements}

We gratefully acknowledge financial support from the National Natural Science Foundation of China (No. U1504207, 21572126), the Key Science Research of Education Committee in Henan Province (19A150035) and the Program of Science and Technology Innovation Talents of Henan Province (2018JQ0011).

\section{Notes and references}

1 (a) J. D. Houwer and B. U. W. Maes, Synthesis, 2014, 2533; (b) S. Messaoudi, A. Hamze, O. Provot, B. Tréguier, J. Rodrigo De Losada, J. Bignon, J.-M. Liu, J. Wdzieczak Bakala, S. Thoret, J. Dubois, J.-D. Brion and M. Alami, ChemMedChem, 2011, 6, 488; (c) A. V. Cheltsov, M. Aoyagi, A. Aleshin, E. C.-W. Yu, T. Gilliland, D. Zhai, A. A. Bobkov, J. C. Reed, R. C. Liddington and R. Abagyan, J. Med. Chem., 2010, 53, 3899; (d) B. Liegault, J.-L. Renaud and C. Bruneau, Chem. Soc. Rev., 2008, 37, 290.

2 (a) V. Ramakrishna, M. J. Rani and N. D. Reddy, Eur. J. Org. Chem., 2017, 48, 7238; (b) G. Zhao, K. Zhang, L. Wang, J. Li, D. Zou, Y. Wu and Y. Wu, Tetrahedron Lett., 2015, 56, 6700; (c) Z. Guan, B. Li, G. Hai, X. Yang, T. Li and B. Tan, RSC Adv., 2014, 4, 36437; (d) M. Micksch, M. Tenne and T. Strassner, Organometallics, 2014, 33, 3966; (e) F. Chahdoura, C. Pradel and M. Gomez, Adv. Synth. Catal., 2013, 355, 3648; (f) K. Karami, C. Rizzoli and M. M. Salah, J. Organomet. Chem., 2011, 696, 940; $(g)$ A. John, M. M. Shaikh, R. J. Butcher and P. Ghosh, Dalton Trans., 2010, 39, 7353; (h) O. Diebolt, V. Jurcik, R. Correada Costa, P. Braunstein, L. Cavallo, S. P. Nolan, A. M. Z. Slawin and
C. S. Cazin, J. Organometallics, 2010, 29, 1443; (i) R. Singh, M. S. Viciu, N. Kramareva, O. Navarro and S. P. Nolan, Org. Lett., 2005, 7, 1829; (j) S. M. Nobre and A. L. Monteiro, Tetrahedron Lett., 2004, 45, 8225.

3 X.-X. Wang, B.-B. Xu, W.-T. Song, K.-X. Sun and J.-M. Lu, Org. Biomol. Chem., 2015, 13, 4925.

4 (a) C. Liu, G. Li, S. Shi, G. Meng, R. Lalancette, R. Szostak and M. Szostak, ACS Catal., 2018, 8, 9131; (b) C. Wang, L. Huang, F. Wang and G. Zou, Tetrahedron Lett., 2018, 59, 2299; (c) P. Lei, G. Meng and M. Szostak, ACS Catal., 2017, 7, 1960; (d) P. Lei, G. Meng, Y. Ling, J. An, S. P. Nolan and M. Szostak, Org. Lett., 2017, 19, 6510; (e) G. Meng, R. Szostak and M. Szostak, Org. Lett., 2017, 19, 3596; $(f)$ P. Lei, G. Meng, Y. Ling, J. An and M. Szostak, J. Org. Chem., 2017, 82, 6638; (g) P. Lei, G. Meng, S. Shi, Y. Ling, J. An, R. Szostak and M. Szostak, Chem. Sci., 2017, 8, 6525; (h) G. Meng, R. Lalancette, R. Szostak and M. Szostak, Org. Lett., 2017, 19, 4656; (i) G. Meng and M. Szostak, Org. Lett., $2015,17,4364$.

5 S. B. Blakey and D. W. C. MacMillan, J. Am. Chem. Soc., 2003, 125, 6046.

6 (a) G. Li, Y. Chen and J. Xia, Chin. J. Org. Chem., 2018, 38, 1949; (b) X.-Y. Liu, H.-B. Zhu, Y.-J. Shen, J. Jiang and T. Tu, Chin. J. Chem., 2017, 28, 350; (c) D. M. Shacklady-McAtee, K. M. Roberts, C. H. Basch, Y.-G. Song and M. P. Watson, Tetrahedron, 2014, 70, 4257; (d) J. T. Reeves, D. R. Fandrick, Z. Tan, J. J. Song, H. Lee, N. K. Yee and C. H. Senanayake, Org. Lett., 2010, 12, 4388; (e) P. Maity, D. M. ShackladyMcAtee, G. P. A. Yap, E. R. Sirianni and M. P. Watson, J. Am. Chem. Soc., 2013, 135, 280.

7 (a) H. J. Davis, M. T. Mihai and R. J. Phipps, J. Am. Chem. Soc., 2016, 138, 12759; (b) F. Zhu, J.-L. Tao and Z.-X. Wang, Org. Lett., 2015, 17, 4926.

8 (a) J. Hu, H. Sun, W. Cai, X. Pu, Y. Zhang and Z. Shi, J. Org. Chem., 2016, 81, 14; (b) C. H. Basch, K. M. Cobb and M. P. Watson, Org. Lett., 2016, 18, 136; (c) H. Zhang, S. Hagihara and K. Itami, Chem. Eur. J., 2015, 21, 16796.

9 T. Moragas, M. Gaydou and R. Martin, Angew. Chem., Int. Ed., 2016, 55, 5053.

10 (a) P. L. Türtscher, H. J. Davis and R. J. Phipps, Synthesis, 2018, 50, 793; (b) T. Wang, S. Yang, S. Xu, C. Han, G. Guo and J. Zhao, RSC Adv., 2017, 7, 15805.

11 (a) T. Wang, K. Xu, A. Zhang, W. Wang and L. Liu, Chin. J. Org. Chem., 2018, 38, 259; (b) T. Wang, H. Xie, L. Liu and W.-X. Zhao, J. Organomet. Chem., 2016, 804, 73.

12 T. Wang, K. Xu, W. Wang, A. Zhang and L. Liu, Transition Met. Chem., 2018, 43, 347.

13 T. Wang, L. Liu, K. Xu, H. Xie, H. Shen and W.-X. Zhao, RSC $A d v .$, 2016, 6, 100690.

14 T. Wang, J. Guo, H. Wang, H. Guo, D. Jia, W. Zhang and L. Liu, J. Organomet. Chem., 2018, 877, 80.

15 K. Ouyang and Z. Xi, Acta Chim. Sinica., 2013, 71, 13.

16 (a) S. Yu, S. Liu, Y. Lan, B. Wan and X. Li, J. Am. Chem. Soc., 2015, 137, 1623; (b) K. H. Jensen and J. E. Hanson, Chem. Mater., 2002, 14, 918. 